\title{
A novel near-infrared fluorescent probe for sensitive detection of $\beta$-galactosidase in living cells
}

Jingtuo Zhang, ${ }^{\text {a }}$ Cong Li, ${ }^{\text {a }}$ Colina Dutta, ${ }^{\text {a }}$ Mingxi Fang, ${ }^{a}$ Shuwei Zhang, ${ }^{\text {a }}$ Ashutosh Tiwari, ${ }^{\text {a* }}$ Thomas Werner, ${ }^{\text {b }}$ Fen-Tair $\mathrm{Luo}^{\mathrm{c} *}$ and Haiying $\mathrm{Liu}^{\mathrm{a} *}$

${ }^{a}$ Department of Chemistry, and ${ }^{\mathrm{b}}$ Department of Biological Sciences, Michigan Technological University, 1400 Townsend Drive, Houghton, MI 49931, USA.

${ }^{\mathrm{c}}$ Institute of Chemistry, Academia Sinica, Taipei, Taiwan 11529, Republic of China.

Corresponding authors:*E-mail: hyliu@mtu.edu; tiwari@mtu.edu; twerner@mtu.edu; luoft@gate.sinica.edu.tw Phone: Tel: 906-487-3451.

\begin{abstract}
:
A novel near-infrared fluorescent probe for $\beta$-galactosidase has been developed based on a hemicyanine skeleton, which is conjugated with a D-galactose residue via a glycosidic bond. The probe serves as a substrate of $\beta$-galactosidase and displays rapid and sensitive turn-on fluorescent responses to $\beta$ galactosidase in aqueous solution. A 12.8-fold enhancement of fluorescence intensity at $703 \mathrm{~nm}$ was observed after incubation of $10 \mathrm{nM}$ of $\beta$-galactosidase with $5 \mu \mathrm{M}$ probe for $10 \mathrm{~min}$. The probe can sensitively detect as little as $0.1 \mathrm{nM}$ of $\beta$-galactosidase and shows linear responses to the enzyme concentration below $1.4 \mathrm{nM}$. The kinetic study showed that the probe has high binding affinity to $\beta$ galactosidase with $\mathrm{K}_{\mathrm{m}}=3.6 \mu \mathrm{M}$. The probe was used to detect $\beta$-galactosidase in living cells by employing the premature cell senescence model. The probe exhibited strong fluorescent signals in senescent cells but not in normal cells, which demonstrats that the probe is able to detect the endogenous senescence-associated $\beta$-galactosidase in living cells.
\end{abstract}


Keywords: $\quad \beta$-Galactosidase, Near-infrared emission, Fluorescent probe, Live cells, fluorescence imaging

\section{Introduction}

$\beta$-Galactosidase $(\beta$-gal), an enzyme that functions to remove galactose residues from gangliosides, glycoproteins, sphingolipids, and keratin sulfate; has been widely used as a marker enzyme to identify cell types, study transcriptional regulation, and investigate gene expression[1]. Thus, developing probes to detect the activity of this important enzyme has been a crucial research topic. In particular, fluorescent probes have provided powerful tools for tracking enzyme activity and attracted researchers' interest over the years because of their non-invasive measurability, high sensitivity, and real-time responses.[2-4] To date, a variety of fluorophores have been used to develop fluorescent probes for the detection of $\beta$-gal activities, such as coumarins[5], 5-bromo-4-chloro-3-hydroxyindole[6], thiazole orange[7], 6(benzo[d]thiazol-2'-yl)-2-(methylamino)-naphthalene[8], fluorescein[9, 10], rhodol[11, 12], fluorescein derivatives[11, 13, 14], and cyanine dyes[15, 16]. However, most fluorescent probes for $\beta$-gal, including commercially available ones such as 4 -ethylumbelliferyl $\beta$-D-galactopyranoside and fluorescein di- $\beta$-Dgalactopyranoside (FDG), emit fluorescence at wavelengths less than $600 \mathrm{~nm}$ and exhibit several in vivo 
application drawbacks, such as low tissue penetration and auto-fluorescence from bio-specimens. In order to overcome these drawbacks and enhance the signal-to-noise ratio, near-infrared fluorescent probes for $\beta$-gal have been prepared by incorporating $\beta$-galactose residues into near-infrared fluorophores such as cyanine and squarylium dye scaffolds[16]. However, only very few near-infrared fluorescent probes have been reported[16]. In this work, we report a near-infrared fluorescent probe (Gal-Pro) for the detection of $\beta$-gal in vitro and visualization of senescence-associated $\beta$-galactosidase (SA- $\beta$-gal) in living cells. Our probe consists of a hemicyanine skeleton ((E)-2-(2-(6-hydroxy-2,3-dihydro-1H-xanthen-4-yl)vinyl)-3,3dimethyl-1-propyl-3H-indol-1-ium) as a fluorophore, where the hydroxyl group is replaced by a $\beta$-Dgalactopyranoside residue that functions as an enzyme recognition and hydrolytic site (Fig. 1). We hypothesized that $\beta$-gal hydrolyzes the glycosidic bond to liberate the strong electron-donating phenolic/phenolate group of the fluorophore. This reaction should result in a dramatic alteration of the intramolecular charge transfer (ICT) status and resonance forms of the fluorophore, causing a red shift of the fluorophore fluorescence spectrum and significant enhancement of its fluorescence intensity.

\section{Materials and Methods}

\subsection{Optical Measurement}

The UV-Vis absorption spectra of Gal-Pro were collected in the range from 300 to $800 \mathrm{~nm}$ with increments of $1 \mathrm{~nm}$. Their corresponding fluorescence spectra were collected at the excitation wavelength of $620 \mathrm{~nm}$ with increments of $1 \mathrm{~nm}$. The excitation and emission slit widths were set to $5 \mathrm{~nm}$. Sulforhodamine 101 dye $(\Phi=0.95$ with excitation wavelength at $577 \mathrm{~nm}$ in ethanol)[17] was used as a standard reference to determine the fluorescence quantum yields of Gal-Pro in buffer solutions. Both samples and references were freshly prepared under identical conditions. The fluorescence quantum yields were calculated using the following equation:

$$
\Phi_{X}=\Phi_{s t}\left(\operatorname{Grad}_{X} / \operatorname{Grad}_{s t}\right)\left(\eta_{X}^{2} / \eta_{s t}^{2}\right)
$$


The subscripts ' $s t$ ' and ' $X$ ' stand for standard and test, respectively. $\Phi$ is the fluorescence quantum yield, "Grad" represents the gradient from the plot of integrated fluorescence intensity versus absorbance, and $\eta$ is the refractive index of the solvent. All optical measurements of Gal-Pro and its cleavage product were carried out in buffer solution (1x PBS, pH 7.4) with 0.5\% DMSO as co-solvent. The photo-stability experiments were conducted using the $620 \mathrm{~nm}$ irradiation beam generated by spectrofluorometer equipped with a $150 \mathrm{~W}$ xenon arc lamp.

\subsection{Live Cell Fluorescence Imaging}

Live cell imaging was carried out using human diploid fibroblast (HDF) cells. Cells were cultured in Eagle's DMEM medium with 10\% FBS, 1x L-glutamine, and 1x penicillin-streptomycin. Cells were plated on 12-well plates at $5 \times 10^{4}$ cells/well and incubated at $37^{\circ} \mathrm{C}$ in a $5 \% \mathrm{CO}_{2}$ incubator overnight. On the next day, the cells were washed three times with 1x PBS and incubated with $150 \mu \mathrm{M} \mathrm{H}_{2} \mathrm{O}_{2}$ for 2 hours at $37^{\circ} \mathrm{C}$ in $5 \% \mathrm{CO}_{2}$ with fresh medium to induce senescence. After 2 hours, the cells were washed three times with 1x PBS and then further incubated with $10 \mu \mathrm{M} \mathrm{H}_{2} \mathrm{O}_{2}$ for 24 hours at $37{ }^{\circ} \mathrm{C}$ in $5 \% \mathrm{CO}_{2}$. Cells without $\mathrm{H}_{2} \mathrm{O}_{2}$ were also incubated as described and used as controls. On the following day, all cells (with/without $\mathrm{H}_{2} \mathrm{O}_{2}$ treatment) were washed and incubated in serum-free medium containing $10 \mu \mathrm{M}$ GalPro for 2 hours. Live cell images were acquired using an inverted fluorescence microscope (AMF-4306, EVOS $_{\mathrm{fl}}, \mathrm{AMG}$ ) with DAPI filter for Hoechst 33342 (Sigma-Aldrich) and CY5 filter for Gal-Pro. The fluorescence images were obtained at 20x magnification. Exposure times for each filter were kept constant.

\subsection{MTS cytotoxicity assay}

The MTS assay was performed with human diploid fibroblast (HDF) cells (ATCC), as previously described[18]. Briefly, the cells were plated at a density of 5000 cells per well on a 96-well cell culture plate and incubated at $37^{\circ} \mathrm{C}$ in a $5 \% \mathrm{CO}_{2}$ incubator overnight. After incubation, the medium was removed, and the cells were washed with $1 \times$ PBS. Fresh medium with $10 \mu \mathrm{M}, 30 \mu \mathrm{M}$, or $100 \mu \mathrm{M}$ of Gal-Pro 
dissolved in DMSO (with <0.5\% DMSO final concentration in medium) were added to the wells and measured in 6 replicates for each dye concentration. Blanks were similarly prepared and had everything except cells. The plates were incubated at $37^{\circ} \mathrm{C}$ in a $5 \% \mathrm{CO}_{2}$ incubator for $48 \mathrm{~h}$. After $48 \mathrm{~h}$ of incubation, $20 \mu \mathrm{L}$ of MTS solution (from CellTiter 96 Aqueous Non-Radioactive Cell proliferation Assay (MTS) kit, Promega) were added to each well. The absorbance at $490 \mathrm{~nm}$ was acquired after a $4 \mathrm{~h}$ incubation at $37^{\circ} \mathrm{C}$, using an ELISA plate reader (BioTek Instruments, Inc.). Plots were normalized to control wells containing medium and cells only.

\subsection{Synthetic procedures:}

2.4.1. Synthesis of (E)-2-(2-(6-hydroxy-2,3-dihydro-1H-xanthen-4-yl)vinyl)-3,3-dimethyl-1-propyl3H-indol-1-ium iodide (Compound 1)

Resorcinol (41.3 mg, $0.38 \mathrm{mmol})$ and $\mathrm{K}_{2} \mathrm{CO}_{3}(52 \mathrm{mg}, 0.38 \mathrm{mmol})$ were dissolved in acetonitrile $(2.5 \mathrm{~mL})$ in a $10 \mathrm{~mL}$ round bottom flask. After the mixture was stirred at room temperature under a nitrogen atmosphere for $15 \mathrm{~min}$, a solution of IR-780 iodide $(100 \mathrm{mg}, 0.15 \mathrm{mmol})$ in acetonitrile $(2.5 \mathrm{~mL})$ was added to the mixture via a syringe. The reaction mixture was heated to $50^{\circ} \mathrm{C}$ and stirred for $5 \mathrm{~h}$. The solvent was then evaporated under reduced pressure, and the crude product was purified by silica gel chromatography, using $\mathrm{CH}_{2} \mathrm{Cl}_{2} / \mathrm{MeOH}(8: 0.7$, v/v) as eluent to obtain compound $\mathbf{1}$ as a blue solid (58.3

mg, 72\%). ${ }^{1} \mathrm{H}$ NMR (400 MHz, $\left.\mathrm{CDCl}_{3}\right) \delta 8.47(\mathrm{~d}, J=13.6 \mathrm{~Hz}, 1 \mathrm{H}), 7.42-7.06(\mathrm{~m}, 8 \mathrm{H}), 6.13(\mathrm{~d}, J=13.8$ $\mathrm{Hz}, 1 \mathrm{H}), 4.14(\mathrm{t}, J=6.0 \mathrm{~Hz}, 2 \mathrm{H}), 2.67(\mathrm{t}, J=4.1 \mathrm{~Hz}, 1 \mathrm{H}), 2.61(\mathrm{t}, J=4.0 \mathrm{~Hz}, 2 \mathrm{H}), 1.89$ (s (br), 4H), 1.71 $(\mathrm{s}, 6 \mathrm{H}), 1.03(\mathrm{t}, J=7.4 \mathrm{~Hz}, 3 \mathrm{H}) .{ }^{13} \mathrm{C} \mathrm{NMR}\left(100 \mathrm{MHz}, \mathrm{CDCl}_{3}\right) \delta 174.7,165.7,162.8,143.6,141.8,141.1$, $137.2,128.7,125.8,124.3,122.3,114.5,111.2,102.7,100.6,94.0,49.7,46.2,28.6,28.4,24.0,20.8,20.4$, 11.5. HRMS (ESI): calculated for $\mathrm{C}_{28} \mathrm{H}_{30} \mathrm{NO}_{2}{ }^{+}[\mathrm{M}-\mathrm{I}]^{+}, 412.2271$; found, 412.2287 .

\subsubsection{Synthesis of 2,3,4,6-tetra- $O$-acetyl- $\alpha$-D-galactopyranosyl bromide (Compound 2)}

To a solution of $\beta$-D-Galactose pentaacetate $(2.2 \mathrm{~g}, 5.58 \mathrm{mmol})$ in acidic acid $(20 \mathrm{~mL})$, acetyl bromide $(1.3 \mathrm{~mL}, 17.52 \mathrm{mmol})$ was added, and the reaction mixture was stirred at room temperature for $2 \mathrm{~h}$ in the 
dark. The solvent was then evaporated under reduced pressure to result in a brown crude product. The crude product was recrystallized in cold ether to give 2,3,4,6-tetra- $O$-acetyl- $\alpha$-D-galactopyranosyl bromide as a white power $(2.0 \mathrm{~g}, 90 \%) .{ }^{1} \mathrm{H}$ NMR $\left(400 \mathrm{MHz}, \mathrm{CDCl}_{3}\right) \delta 6.65(\mathrm{~d}, J=3.9 \mathrm{~Hz}, 1 \mathrm{H}), 5.46(\mathrm{dd}$, $\left.J_{l}=3.2, J_{2}=1.2 \mathrm{~Hz}, 1 \mathrm{H}\right), 5.35\left(\mathrm{dd}, J_{l}=10.7, J_{2}=3.3 \mathrm{~Hz}, 1 \mathrm{H}\right), 4.99\left(\mathrm{dd}, J_{l}=10.7, J_{2}=3.9 \mathrm{~Hz}, 1 \mathrm{H}\right), 4.44$ $(\mathrm{t}, J=6.7 \mathrm{~Hz}, 1 \mathrm{H}), 4.14\left(\mathrm{dd}, J_{l}=11.4, J_{2}=6.3 \mathrm{~Hz}, 1 \mathrm{H}\right), 4.06\left(\mathrm{dd}, J_{l}=11.4, J_{2}=6.8 \mathrm{~Hz}, 1 \mathrm{H}\right), 2.10(\mathrm{~s}, 3 \mathrm{H})$, 2.06 (s, 3H), 2.00 (s, 3H), 1.96 (s, 3H). $\left.{ }^{13} \mathrm{C} \mathrm{NMR} \mathrm{(101} \mathrm{MHz,} \mathrm{CDCl}_{3}\right) \delta 170.2,170.0,169.8,169.7,88.1$, 71.0, 67.9, 67.7, 66.9, 60.8, 20.7, 20.6, 20.5, 15.2. HRMS (FAB): calculated for $\mathrm{C}_{14} \mathrm{H}_{20} \mathrm{BrO}_{9}^{+}[\mathrm{M}+\mathrm{H}]^{+}$, 411.0285; found, 411.0291.

\subsubsection{Synthesis of 3,3-dimethyl-1-propyl-2-((E)-2-(6-(((2S,3R,4S,5S,6R)-3,4,5-triacetoxy-6- (acetoxymethyl)tetrahydro-2H-pyran-2-yl)oxy)-2,3-dihydro-1H-xanthen-4-yl)vinyl)-3H-indol-1-ium iodide (compound 3)}

Compound 1 (30 mg, $0.056 \mathrm{mmol})$ and $\mathrm{Cs}_{2} \mathrm{CO}_{3}(70 \mathrm{mg}, 0.21 \mathrm{mmol})$ were dissolved in dry $\mathrm{CH}_{2} \mathrm{Cl}_{2}(3 \mathrm{~mL})$ in a $10 \mathrm{~mL}$ round flask and stirred at room temperature under a nitrogen atmosphere for $15 \mathrm{~min}$. Compound 2 ( $88 \mathrm{mg}, 0.21 \mathrm{mmol}$ ) was then added, and the reaction mixture was further stirred at room temperature for $12 \mathrm{~h}$. After that, the solvent was removed under reduced pressure and the resulting residue was purified by silica gel chromatography, using $\mathrm{CH}_{2} \mathrm{Cl}_{2} / \mathrm{MeOH}(8: 0.6$, v/v) as eluent to obtain compound 3 as a blue solid (28.2 mg, 58\%). ${ }^{1} \mathrm{H}$ NMR (400 MHz, $\left.\mathrm{CDCl}_{3}\right) \delta 8.67(\mathrm{~d}, J=15.0 \mathrm{~Hz}, 1 \mathrm{H})$, $7.54-7.36(\mathrm{~m}, 5 \mathrm{H}), 7.22(\mathrm{~s}, 1 \mathrm{H}), 7.09(\mathrm{~d}, J=1.9 \mathrm{~Hz}, 1 \mathrm{H}), 6.97\left(\mathrm{dd}, J_{l}=8.6, J_{2}=2.3 \mathrm{~Hz}, 1 \mathrm{H}\right), 6.60(\mathrm{~d}, J$ $=15.0 \mathrm{~Hz}, 1 \mathrm{H}), 5.56-5.46(\mathrm{~m}, 3 \mathrm{H}), 5.24\left(\mathrm{dd}, J_{I}=10.1, J_{2}=3.5 \mathrm{~Hz}, 1 \mathrm{H}\right), 4.52\left(\mathrm{td}, J_{I}=7.1, J_{2}=3.2 \mathrm{~Hz}\right.$, $2 \mathrm{H}), 4.43(\mathrm{t}, J=6.8 \mathrm{~Hz}, 1 \mathrm{H}), 4.26\left(\mathrm{dd}, J_{l}=11.2, J_{2}=6.5 \mathrm{~Hz}, 1 \mathrm{H}\right), 4.11\left(\mathrm{dd}, J_{l}=11.2, J_{2}=7.2 \mathrm{~Hz}, 1 \mathrm{H}\right)$, $2.75\left(\mathrm{dt}, J_{1}=12.2, J_{2}=10.8 \mathrm{~Hz}, 4 \mathrm{H}\right), 2.18(\mathrm{~d}, J=8.5 \mathrm{~Hz}, 3 \mathrm{H}), 2.07(\mathrm{~s}, 3 \mathrm{H}), 2.03(\mathrm{~s}, 3 \mathrm{H}), 2.00(\mathrm{~s}, 3 \mathrm{H})$, $1.99-1.88(\mathrm{~m}, 4 \mathrm{H}), 1.82(\mathrm{~d}, J=3.1 \mathrm{~Hz}, 6 \mathrm{H}), 1.07(\mathrm{t}, J=7.4 \mathrm{~Hz}, 3 \mathrm{H}) .{ }^{13} \mathrm{C} \mathrm{NMR}\left(101 \mathrm{MHz}, \mathrm{CDCl}_{3}\right) \delta$ $178.34,170.54,170.29,169.95,161.08,159.35,154.11,146.35,142.30,141.73,132.70,129.40,128.85$ $127.72,122.74,117.68,115.49,114.12,113.22,105.49,104.79,98.53,71.19,70.95,68.81,67.01,61.15$, 
51.13, 47.91, 29.52, 28.64, 28.37, 24.78, 21.68, 20.91, 20.49, 11.80. HRMS (ESI): calculated for $\mathrm{C}_{42} \mathrm{H}_{48} \mathrm{NO}_{11}^{+}[\mathrm{M}-\mathrm{I}]^{+}, 742.3222$; found, 742.3247.

\subsubsection{Synthesis of fluorescent probe Gal-Pro}

To a solution of compound $3(20 \mathrm{mg}, 0.023 \mathrm{mmol})$ in methanol $(2 \mathrm{~mL}), \mathrm{K}_{2} \mathrm{CO}_{3}(13 \mathrm{mg}, 0.094 \mathrm{mmol})$ was added, and the reaction mixture was stirred at room temperature for $2 \mathrm{~h}$. After that, the solvent was evaporated under reduced pressure, and the crude was purified by preparative TLC, using $\mathrm{CH}_{2} \mathrm{Cl}_{2} / \mathrm{MeOH}$ (8:1 to 7:1, v/v) as eluent to obtain Gal-Pro as a blue solid (10.2 mg, 63\%). ${ }^{1} \mathrm{H}$ NMR (400 MHz, $\left.\mathrm{CD}_{3} \mathrm{OD}\right)$ $\delta 8.81(\mathrm{~d}, J=15.0 \mathrm{~Hz}, 1 \mathrm{H}), 7.69(\mathrm{~d}, J=7.4 \mathrm{~Hz}, 1 \mathrm{H}), 7.62-7.43(\mathrm{~m}, 4 \mathrm{H}), 7.39(\mathrm{~s}, 1 \mathrm{H}), 7.23(\mathrm{~d}, J=2.3 \mathrm{~Hz}$, 1H), $7.12(\mathrm{dd}, J=8.6,2.3 \mathrm{~Hz}, 1 \mathrm{H}), 6.56(\mathrm{~d}, J=14.9 \mathrm{~Hz}, 1 \mathrm{H}), 5.02(\mathrm{~d}, J=7.7 \mathrm{~Hz}, 1 \mathrm{H}), 4.36(\mathrm{t}, J=8.0 \mathrm{~Hz}$, 2H), $3.95(\mathrm{~d}, J=3.4 \mathrm{~Hz}, 1 \mathrm{H}), 3.90-3.78(\mathrm{~m}, 4 \mathrm{H}), 3.64(\mathrm{dd}, J=9.7,3.4 \mathrm{~Hz}, 1 \mathrm{H}), 2.80(\mathrm{t}, J=6.0 \mathrm{~Hz} 2 \mathrm{H})$, $2.73(\mathrm{t}, J=5.9 \mathrm{~Hz}, 1 \mathrm{H}), 2.00-1.90(\mathrm{~m}, 4 \mathrm{H}), 1.85(\mathrm{~s}, 3 \mathrm{H}), 1.83(\mathrm{~s}, 3 \mathrm{H}), 1.08(\mathrm{t}, J=7.4 \mathrm{~Hz}, 3 \mathrm{H}) .{ }^{13} \mathrm{C} \mathrm{NMR}$ $\left(101 \mathrm{MHz}, \mathrm{CD}_{3} \mathrm{OD}\right) \delta 179.7,162.7,162.3,147.4,143.7,143.0,130.2,129.9,129.3,128.5,123.8,118.3$, 115.7, 114.1, 105.2, 104.7, 103.0, 95.8, 77.6, 74.8, 72.1, 70.3, 62.7, 52.2, 30.1, 28.4, 28.4, 25.0, 22.3, 21.6, 11.6. HRMS (ESI): calculated for $\mathrm{C}_{34} \mathrm{H}_{40} \mathrm{NO}_{7}{ }^{+}[\mathrm{M}-\mathrm{I}]^{+}$, 574.2799; found, 574.2798.

\section{Results and discussions:}

\subsection{Synthesis}

The synthetic route to our fluorescent probe for the detection of $\beta$-gal is outlined in Scheme 1. First, the cyanine dye IR-780 (a chloro-substituted tricarbocyanine dye) was reacted with resorcin under a basic condition $\left(\mathrm{K}_{2} \mathrm{CO}_{3}\right)$ in acetonitrile, yielding the near-infrared emissive (E)-2-(2-(6-hydroxy-2,3-dihydro1H-xanthen-4-yl)vinyl)-3,3-dimethyl-1-propyl-3H-indol-1-ium iodide (1), which contains a phenolic hemicyanine skeleton[19, 20]. Compound 1 was further reacted with 2,3,4,6-tetra- $O$-acetyl- $\beta$-galactosyl bromide (2) through a nucleophilic substitution in the presence of $\mathrm{Cs}_{2} \mathrm{CO}_{3}$ to generate an intermediate 3 with a glycosidic bond between the fluorophore and carbohydrate. The subsequent mild de-acetylation of intermediate 3 in methanol containing $\mathrm{K}_{2} \mathrm{CO}_{3}$ resulted in the fluorescent probe Gal-Pro. 


\subsection{Optical responses of Gal-Pro to $\beta$-gal}

We next examined the optical properties of our fluorescent probe and studied its responses to $\beta$-gal in an aqueous buffer solution. In the absence of $\beta$-gal, the probe showed a deep blue color in PBS with the highest absorption peak at $596 \mathrm{~nm}\left(\varepsilon=3.75 \times 10^{4} \mathrm{~cm}^{-1} \mathrm{M}^{-1}\right)$ and two smaller peaks at $560 \mathrm{~nm}$ and $643 \mathrm{~nm}$. The fluorescent probe displayed extremely weak fluorescence with a maximum peak at $665 \mathrm{~nm}$ and a fluorescent quantum yield $(\Phi)$ of $0.1 \%$ in PBS solution in the absence of $\beta$-gal. However, in the presence of $\beta$-gal, our probe reacted with $\beta$-gal very efficiently and triggered a strong fluorescence. The product of this hydrolytic reaction was confirmed by ESI-MS to be the free phenolic/phenolate form (compound 1, $\left.\varepsilon_{(682 \mathrm{~nm})}=3.3 \times 10^{4} \mathrm{~cm}^{-1} \mathrm{M}^{-1}, \Phi=0.20[21]\right)$, which was associated with a new peak at $\mathrm{m} / \mathrm{z} 412.3$ (Fig. S1). Upon incubation with $\beta$-gal at $37^{\circ} \mathrm{C}$, the fluorescent probe exhibited a strong and rapid fluorescence turnon within $10 \mathrm{~min}$, which was associated with the emergence of a new emission peak at $703 \mathrm{~nm}$ (Fig. 2a, c). This peak may have arisen from the formation of a more stable zwitterionic resonance form of the probe with free phenolate after the enzymatic cleavage. When we increased the $\beta$-gal concentration from sub-nanomolar to nanomolar concentrations, the fluorescence of the probe gradually increased. At 703 nm, we observed a 12.8-fold fluorescence enhancement when $10 \mathrm{nM}$ of $\beta$-gal were incubated with the probe. Plotting the fluorescence intensity at $703 \mathrm{~nm}$ against the $\beta$-gal concentration resulted in a logarithmic response curve that displays high sensitivity (as low as $0.1 \mathrm{nM}$ of $\beta$-gal) with a calculated detection limit of $0.057 \mathrm{nM}$ based on $\mathrm{S} / \mathrm{N}=3$ (Fig. 2d). Additionally, the curve showed very good linearity $\left(r^{2}=0.99367\right)$ below $1.4 \mathrm{nM}$ of enzyme, indicating the potential quantitation capability of our probe to $\beta$-gal at low concentration levels (Fig. $2 \mathrm{~d}$ ). The reaction between the probe and $\beta$-gal also resulted in significant changes of the probe absorption spectra. A new absorption peak at $682 \mathrm{~nm}$ appeared, while the peaks at $560 \mathrm{~nm}, 596 \mathrm{~nm}$, and $643 \mathrm{~nm}$ decreased after a 10 min incubation of the probe with $\beta$-gal at $37^{\circ} \mathrm{C}$, leading to a significant color change of the solution from deep blue to cyan, which can be easily distinguished with the naked eye (Fig. 2b, e). The rise of longer-wavelength peaks 
both in absorption and fluorescence spectra are characteristic for the enhanced ICT effect from the electron-pushing phenolate group to the hemicyanine core of the probe after the enzymatic cleavage.

\subsection{Gal-Pro kinetics and sensing efficiency}

To further quantify the sensing efficiency, we investigated the apparent steady-state kinetics of the enzymatic reaction between $\beta$-gal and the fluorescent probe. By plotting the initial reaction velocity as the function of the probe concentration, a typical Michaelis-Menten curve was obtained (Fig. 3). Further nonlinear fitting of this plot using the Michaelis-Menten equation $\left(v=V_{\max }[\mathrm{S}] /\left(K_{\mathrm{m}}+[\mathrm{S}]\right)\right)$ revealed the kinetic parameters of the reaction with a Michaelis-Menten constant $\left(K_{\mathrm{m}}\right)=3.6 \mu \mathrm{M}$, maximum rate $\left(V_{\max }\right)$ $=7.9 \mathrm{nM} \cdot \mathrm{s}^{-1}$, catalytic constant $\left(k_{\text {cat }}\right)=7.9 \mathrm{~s}^{-1}$ and catalytic efficiency $=2.2 \mu \mathrm{M}^{-1} \cdot \mathrm{s}^{-1}$. We then compared our probe with the commercially available probe FDG and two more recently reported $\beta$-gal probes SG1[8] and DCM- $\beta$ gal[22] in terms of emission wavelength for detection, detection limit, and catalytic efficiency (Table S1). Although these reported probes possess different advantages, we concluded that our probe Gal-Pro shows several improvements. For instance, Gal-Pro generates the longest emission wavelength for the detection among these probes. Similar to SG1, Gal-Pro also has much smaller $K_{\mathrm{m}}$ and larger $k_{\text {cat }} / K_{\mathrm{m}}$ values compared to FDG $\left(K_{\mathrm{m}}=10.2 \mu \mathrm{M}, k_{\mathrm{cat}} / K_{\mathrm{m}}=0.0157 \mu \mathrm{M}^{-1} \cdot \mathrm{s}^{-1}\right)$ and DCM- $\beta$ gal $\left(K_{\mathrm{m}}=\right.$ $\left.60.1 \mu \mathrm{M}, k_{\mathrm{cat}} / K_{\mathrm{m}}=0.48 \mu \mathrm{M}^{-1} \cdot \mathrm{s}^{-1}\right)[8,22]$, suggesting that our probe has a high affinity for $\beta$-gal and is an efficient substrate for this enzymatic catalysis. In addition, Gal-Pro exhibits a lower detection limit of $0.057 \mathrm{nM}$, as compared to SG1's $0.25 \mathrm{nM}$. Taking all these parameters together, it is clear that Gal-Pro is a sensitive and efficient probe for the detection of $\beta$-gal.

\subsection{Selectivity}

Additionally, we tested the response of our probe to $\beta$-gal under potentially interfering conditions to see the effects on the binding between enzyme and substrate. We measured the probe responses to $\beta$-gal under two conditions: 1) in the presence of D-galactose, a well-known competitive inhibitor of $\beta$-gal, and 2) in the presence of D-glucose, the most abundant mono-carbohydrate serving as energy source in cells. 
As expected, the presence of D-galactose in the sensing system significantly suppressed the fluorescence turn-on of the probe in a concentration-dependent manner. However, when compared to D-galactose, Dglucose did not show a significant effect on the probe response, although there was a slight decrease in fluorescence especially at high glucose concentrations (50 and $100 \mathrm{mM}$ ) (Fig. 4). These results confirm that our probe functions as a substrate of $\beta$-gal, and that its binding to $\beta$-gal can be significantly affected by $\beta$-gal inhibitors but almost not by non-inhibiting carbohydrates such as D-glucose.

\subsection{Photo-stability and thermo-stability}

We further evaluated the photo-stability of the fluorescent probe, its enzyme cleavage product (compound 1), and compared it to the widely used commercial near-infrared dyes IR-780 and IR-820 using a timedependent fluorescence experiment. Within $3 \mathrm{~h}$ of illumination at $620 \mathrm{~nm}$, the fluorescent probe did not show any recognizable change in fluorescence intensity, and the fluorescence of its cleavage product (compound 1) exhibited a very small change with less than $5 \%$ of decrease, as compared to the initial intensity (Fig. 5). In contrast, both of the commercial dyes IR-780 and IR-820 showed noticeable photobleaching under the same condition. IR-780 lost $15 \%$ of its fluorescence after $3 \mathrm{~h}$ illumination, and IR820 showed a fluorescence drop of over $60 \%$ after only $40 \mathrm{~min}$ (Fig. 5). This marked difference indicated that our sensing system, including the probe and its sensing product, are resistant to photo-bleaching, a highly desirable property for fluorescent probes. Beside the photo-stability, the probe's thermo-stability is also critical as many of near-infrared cyanine derivatives are sensitive to heat and can undergo decomposition at physiological temperature. Thus, we examined the time-dependent fluorescent intensity changes $(F)$ of Gal-Pro and its enzyme cleavage product (compound 1) at four different temperatures.

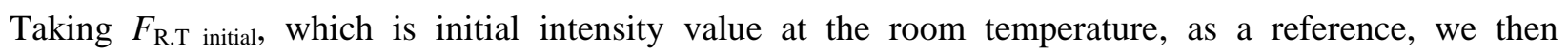
calculated the ratio of $F$ to $F_{\text {R.T initial }}$ and plotted it against time to evaluate the thermos-stability of Gal-Pro and compound 1(Fig 6). We found that the fluorescent intensities of Gal-Pro at room temperature ( $25^{\circ} \mathrm{C}$ ), $30^{\circ} \mathrm{C}$ and $37^{\circ} \mathrm{C}$ did not exhibit obvious differences, and they were quite stable over the course of 3 hours with less than a $5 \%$ reduction. A higher temperature $\left(45^{\circ} \mathrm{C}\right)$ led to considerable quenching of Gal- 
Pro's fluorescence by $20 \%$, as compared to the value at room temperature, probably due to self-quenching caused by the higher rate of intermolecular collision at $45^{\circ} \mathrm{C}$ (Fig 6a). Interestingly, the strongly fluorescent compound $\mathbf{1}$ also did not show any significant change in fluorescent intensity at room temperature, $30^{\circ} \mathrm{C}, 37^{\circ} \mathrm{C}$, and even at $45^{\circ} \mathrm{C}$; it retained $90 \%$ of its initial fluorescent intensity after $3 \mathrm{~h}$ of incubation at all four different temperature conditions (Fig 6b). These results indicate that our probe is thermostable and is able to generate stable sensing signals at physiological temperature.

\subsection{Fluorescence imaging of SA- $\beta$-gal in living cells}

Finally, we applied the fluorescent probe Gal-Pro to living cells to detect the endogenous senescenceassociated $\beta$-galactosidase (SA- $\beta$-gal) by employing the premature cell senescence model that can be induced by treating the cells with hydrogen peroxide. SA- $\beta$-gal is overexpressed endogenously in aged cells and has been extensively used as a biomarker for senescent and aging cells[23, 24], including $\mathrm{H}_{2} \mathrm{O}_{2-}$ induced premature senescent cells[25]. However, treating cells with $\mathrm{H}_{2} \mathrm{O}_{2}$ significantly increases the intracellular levels of reactive oxygen species (ROS), which can potentially interfere with the sensing system if ROS interact with our probe. Thus, we first investigated the responses of our probe to different ROS such as $\mathrm{H}_{2} \mathrm{O}_{2}, \mathrm{ClO}^{-}, \cdot \mathrm{OH}$, and $\mathrm{O}_{2}^{-}$. When we incubated $5 \mu \mathrm{M}$ of Gal-Pro with $100 \mu \mathrm{M}$ of each ROS for $30 \mathrm{~min}$, the probe showed no responses to these ROSs (Fig. S2). In addition, we calculated the $\log$ P value of Gal-Pro with the ALOGPS 2.1 program[26]. Compared to FDG ( $\log P=0.24)$, Gal-Pro has a higher $\log \mathrm{P}$ value of 1.7 , indicating a more appropriate lipophilicity of our probe which can lead to a good membrane permeability when applied to live cells. To detect SA- $\beta$-gal, we incubated premature senescent human diploid fibroblast (HDF) cells with $10 \mu \mathrm{M}$ of the fluorescent probe for $2 \mathrm{~h}$ before observing them under the fluorescence microscope. Ten $\mu \mathrm{M}$ of the fluorescent probe were used because this concentration showed low cytotoxicity to the HDF cells ( $90 \%$ of cells remained alive after $48 \mathrm{~h}$ of incubation) based on the MTS assay, while higher concentrations $(30 \mu \mathrm{M}$ and $50 \mu \mathrm{M})$ were more toxic to cells (Fig. 6). The premature senescent cells were obtained according to the reported procedure[27, 28], in which the normal HDF cells were treated with $150 \mu \mathrm{M}$ of $\mathrm{H}_{2} \mathrm{O}_{2}$ for $2 \mathrm{~h}$, followed by a $24 \mathrm{~h}$ incubation with $10 \mu \mathrm{M}$ of $\mathrm{H}_{2} \mathrm{O}_{2}$. 
SA- $\beta$-gal activity of these senescent cells was additionally confirmed by conventional colorimetric X-gal staining at $\mathrm{pH}$ 6.0, using a commercial senescence detection kit (Fig. S3). The control group contained untreated (non-senescent) HDF cells. While no obvious fluorescence was observed in untreated HDF cells after incubating with the fluorescent probe, the senescent HDF cells showed strong turn-on NIR fluorescence under the same conditions (Fig. 7). This result demonstrates that the probe can efficiently detect SA- $\beta$-gal in live senescent cells.

\section{Conclusion}

In conclusion, we have developed a novel near-infrared fluorescent probe for the sensitive detection of $\beta$ gal. The probe shows quick turn-on fluorescence responses to $\beta$-gal with excellent sensitivity and photostability. We successfully used the fluorescent probe to detect senescence-associated $\beta$-galactosidase in living cells. Incubation of premature senescent cells with the fluorescent probe resulted in a significant increase in fluorescence, while no turn-on signal was observed in the control cells, demonstrating the capability of the fluorescent probe in monitoring $\beta$-galactosidase activity in senescent cells.

\section{Acknowledgements}

The research reported in this publication was partially supported by the National Institute of General Medical Sciences of the National Institutes of Health under Award Number R15GM114751 (to H.Y. Liu and A. Tiwari) and the National Science Foundation (award number 1048655) (to H. Y. Liu).

\section{References}

[1] T. Komatsu, Y. Urano, Evaluation of enzymatic activities in living systems with smallmolecular fluorescent substrate probes, Anal. Sci., 31 (2015) 257-265.

[2] G.B. Ge, J. Ning, L.H. Hu, Z.R. Dai, J. Hou, Y.F. Cao, Z.W. Yu, C.Z. Ai, J.K. Gu, X.C. Ma, L. Yang, A highly selective probe for human cytochrome P450 3A4: isoform selectivity, kinetic characterization and its applications, Chem. Commun., 49 (2013) 9779-9781. 
[3] Z.R. Dai, G.B. Ge, L. Feng, J. Ning, L.H. Hu, Q. Jin, D.D. Wang, X. Lv, T.Y. Dou, J.N. Cui, L. Yang, A Highly Selective Ratiometric Two-Photon Fluorescent Probe for Human Cytochrome P450 1A, J. Am. Chem. Soc., 137 (2015) 14488-14495.

[4] L.W. Zou, P. Wang, Q. X.K., F. L., Y. Yu, D.D. Wang, Q. Jin, J. Hou, Z.H. Lui, G.B. Ge, Y. L., A highly specific ratiometric two-photon fluorescent probe to detect dipeptidyl peptidase IV in plasma and living systems, Biosens. Bioelectron., 90 (2017) 283-289.

[5] K.F. Chilvers, J.D. Perry, A.L. James, R.H. Reed, Synthesis and evaluation of novel fluorogenic substrates for the detection of bacterial $\beta$-galactosidase, J. Appl. Microbiol., 91 (2001) 1118-1130.

[6] T. Otsubo, A. Minami, H. Fujii, R. Taguchi, T. Takahashi, T. Suzuki, F. Teraoka, K. Ikeda, 2 (Benzothiazol-2-yl)-phenyl- $\beta$-D-galactopyranoside derivatives as fluorescent pigment dyeing substrates and their application for the assay of $\beta$-D-galactosidase activities, Bioorg. Med. Chem. Lett., 23 (2013) 2245-2249.

[7] Y. Koide, Y. Urano, A. Yatsushige, K. Hanaoka, T. Terai, T. Nagano, Design and development of enzymatically activatable photosensitizer based on unique characteristics of thiazole orange, J. Am. Chem. Soc., 131 (2009) 6058-6059.

[8] H.W. Lee, C.H. Heo, D. Sen, H.O. Byun, I.H. Kwak, G. Yoon, H.M.Y. Kim, Ratiometric twophoton fluorescent probe for quantitative detection of $\beta$-galactosidase activity in senescent cells, Anal. Chem., 86 (2014) 10001-10005.

[9] P.K. Mandal, L. Cattiaux, D. Bensimon, J.M. Mallet, Monogalactopyranosides of fluorescein and fluorescein methyl ester: synthesis, enzymatic hydrolysis by biotnylated $\beta$-galactosidase, and determination of translational diffusion coefficient, Carbohydr. Res., 358 (2012) 40-46.

[10] Y. Urano, M. Kamiya, K. Kanda, T. Ueno, K. Hirose, T. Nagano, Evolution of fluorescein as a platform for finely tunable fluorescence probes, J. Am. Chem. Soc., 127 (2005) 4888-4894.

[11] Y. Ichikawa, M. Kamiya, F. Obata, M. Miura, T. Terai, T. Komatsu, T. Ueno, K. Hanaoka, T. Nagano, Y. Urano, Selective ablation of $\beta$-galactosidase-expressing cells with a rationally designed activatable photosensitizer, Angew. Chem., Int. Ed., 53 (2014) 6772-6775.

[12] M. Kamiya, D. Asanuma, E. Kuranaga, A. Takeishi, M. Sakabe, M. Miura, T. Nagano, Y. Urano, $\beta$-Galactosidase fluorescence probe with improved cellular accumulation based on a spirocyclized rhodol scaffold, J. Am. Chem. Soc., 133 (2011) 12960-12963.

[13] T. Egawa, Y. Koide, K. Hanaoka, T. Komatsu, T. Terai, T. Nagano, Development of a fluorescein analogue, TokyoMagenta, as a novel scaffold for fluorescence probes in red region, Chem. Commun., 47 (2011) 4162-4164. 
[14] K. Hirabayshi, K. Hanaoka, T. Takayanagi, Y. Toki, T. Egawa, M. Kamiya, T. Komatsu, T. Ueno, T. Terai, K. Yoshida, M. Uchiyama, T. Nagano, Y. Urano, Analysis of chemical equilibrium of silicon-substituted fluorescein and its application to develop a scaffold for red fluorescent probes, Anal. Chem., 87 (2015) 9061-9069.

[15] J.Y. Han, M.S. Han, C.H. Tung, A fluorogenic probe for $\beta$-galactosidase activity imaging in living cells, Mol. BioSyst., 9 (2013) 3001-3008.

[16] D. Oushiki, H. Kojima, Y. Takahashi, T. Komatsu, T. Terai, K. Hanaoka, M. Nishikawa, Y. Takakura, T. Nagano, Near-infrared fluorescence probes for enzymes based on binding affinity modulation of squarylium dye scaffold, Anal. Chem., 84 (2012) 4404-4410.

[17] R.A. Velapoldi, H.H. Tonnesen, Corrected emission spectra and quantum yields for a series of fluorescent compounds in the visible spectral region, J. Fluoresc., 14 (2004) 465-472.

[18] X.C. Ding, J. Janjanam, A. Tiwari, M. Thompson, P.A. Heiden, Peptide-Directed SelfAssembly of Functionalized Polymeric Nanoparticles Part I: Design and Self-Assembly of Peptide-Copolymer Conjugates into Nanoparticle Fibers and 3D Scaffolds, Macromol. Biosci., 14 (2014) 853-871.

[19] L. Yuan, W.Y. Lin, S. Zhao, W.S. Gao, B. Chen, L.W. He, S.S. Zhu, A unique approach to development of near-infrared fluorescent sensors for in vivo imaging, J. Am. Chem. Soc., 134 (2012) 13510-13523.

[20] Z. Li, X.Y. He, Z. Wang, R.H. Yang, W. Shi, H.M. Ma, in vivo imaging and detection of nitroreductase in zebrafish by a new near-infrared fluorescence off-on probe, Biosensors \& Bioelectronics, 63 (2015) 112-116.

[21] X.F. Wu, L.H. Li, W. Shi, Q.Y. Gong, H.M. Ma, Near-Infrared Fluorescent Probe with New Recognition Moiety for Specific Detection of Tyrosinase Activity: Design, Synthesis, and Application in Living Cells and Zebrafish, Angewandte Chemie-International Edition, 55 (2016) 14728-14732.

[22] K.Z. Gu, Y.S. Xu, H. Li, Z.Q. Guo, S.J. Zhu, S.Q. Zhu, P. Shi, T.D. James, H. Tian, W.H. Zhu, Real-Time Tracking and In Vivo Visualization of beta-Galactosidase Activity in Colorectal Tumor with a Ratiometric Near-Infrared Fluorescent Probe, Journal of the American Chemical Society, 138 (2016) 5334-5340.

[23] G.P. Dimri, X.H. Lee, G. Basile, M. Acosta, C. Scott, C. Roskelley, E.E. Medrano, M. Linskens, I. Rubelj, O. Pereirasmith, M. Peacocke, J. Campisi, A biomarker that identifies senescent human-cells in culture and in aging skin in-vivo, Proc. Natl. Acad. Sci. U. S. A., 92 (1995) 9363-9367. 
[24] B.Y. Lee, J.A. Han, J.S. Im, A. Morrone, K. Johung, E.C. Goodwin, W.J. Kleijer, D. DiMaio, E.S. Hwang, Senescence-associated $\beta$-galactosidase is lysosomal $\beta$-galactosidase, Aging Cell, 5 (2006) 187-195.

[25] Q.M. Chen, V.C. Tu, J.P. Liu, Measurements of hydrogen peroxide induced premature senescence: Senescence-associated $\beta$-galactosidase and DNA synthesis index in human diploid fibroblasts with down-regulated p53 or Rb, Biogerontology, 1 (2000) 335-339.

[26] I.V. Tetko, V.Y. Tanchuk, Application of associative neural networks for prediction of lipophilicity in ALOGPS 2.1 program, Journal of Chemical Information and Computer Sciences, 42 (2002) 1136-1145.

[27] Q. Chen, B.N. Ames, Senescence-like growth arrest induced by hydrogen-peroxide in human-diploid fibroblast F65 cells, Proc. Natl. Acad. Sci. U. S. A., 91 (1994) 4130-4134.

[28] C. Frippiat, Q.M. Chen, S. Zdanov, J.P. Magalhaes, J. Remacle, O. Toussaint, Subcytotoxic $\mathrm{H} 2 \mathrm{O} 2$ stress triggers a release of transforming growth factor-beta 1, which induces biomarkers of cellular senescence of human diploid fibroblasts, J. Biol. Chem., 276 (2001) 2531-2537. 


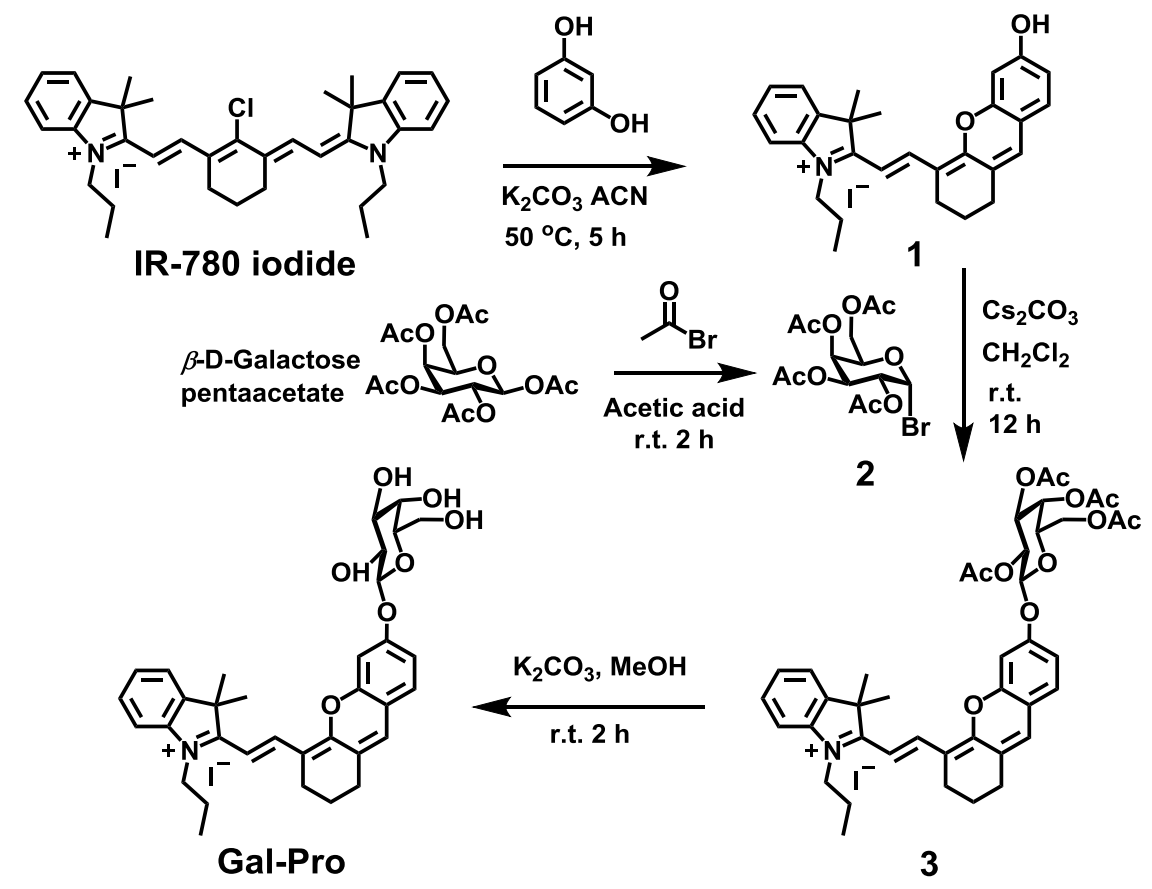

Scheme 1 Synthetic route to fluorescent $\beta$-gal probe Gal-Pro. 

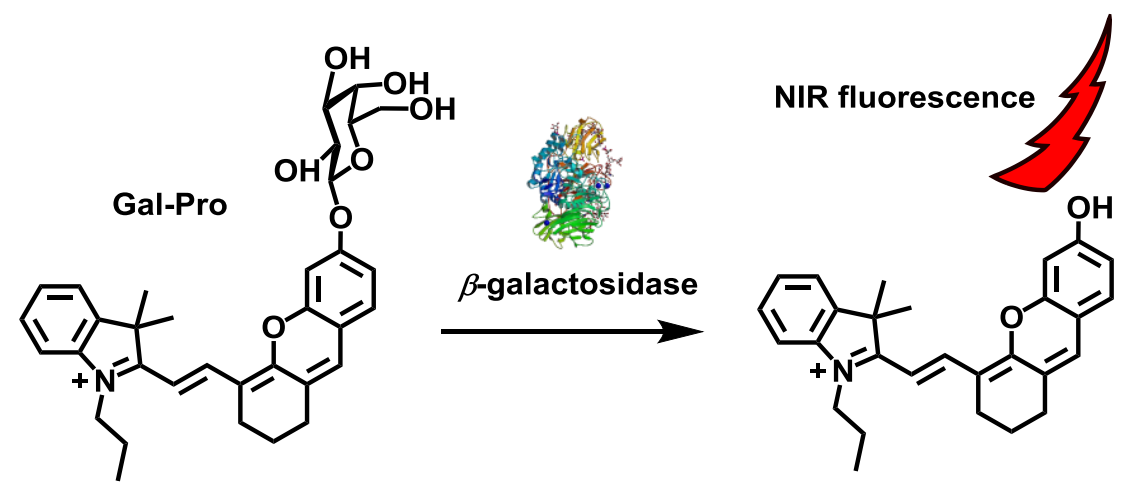

Fig. 1 The design of the near-infrared fluorescent turn-on probe Gal-Pro for $\beta$-gal. 

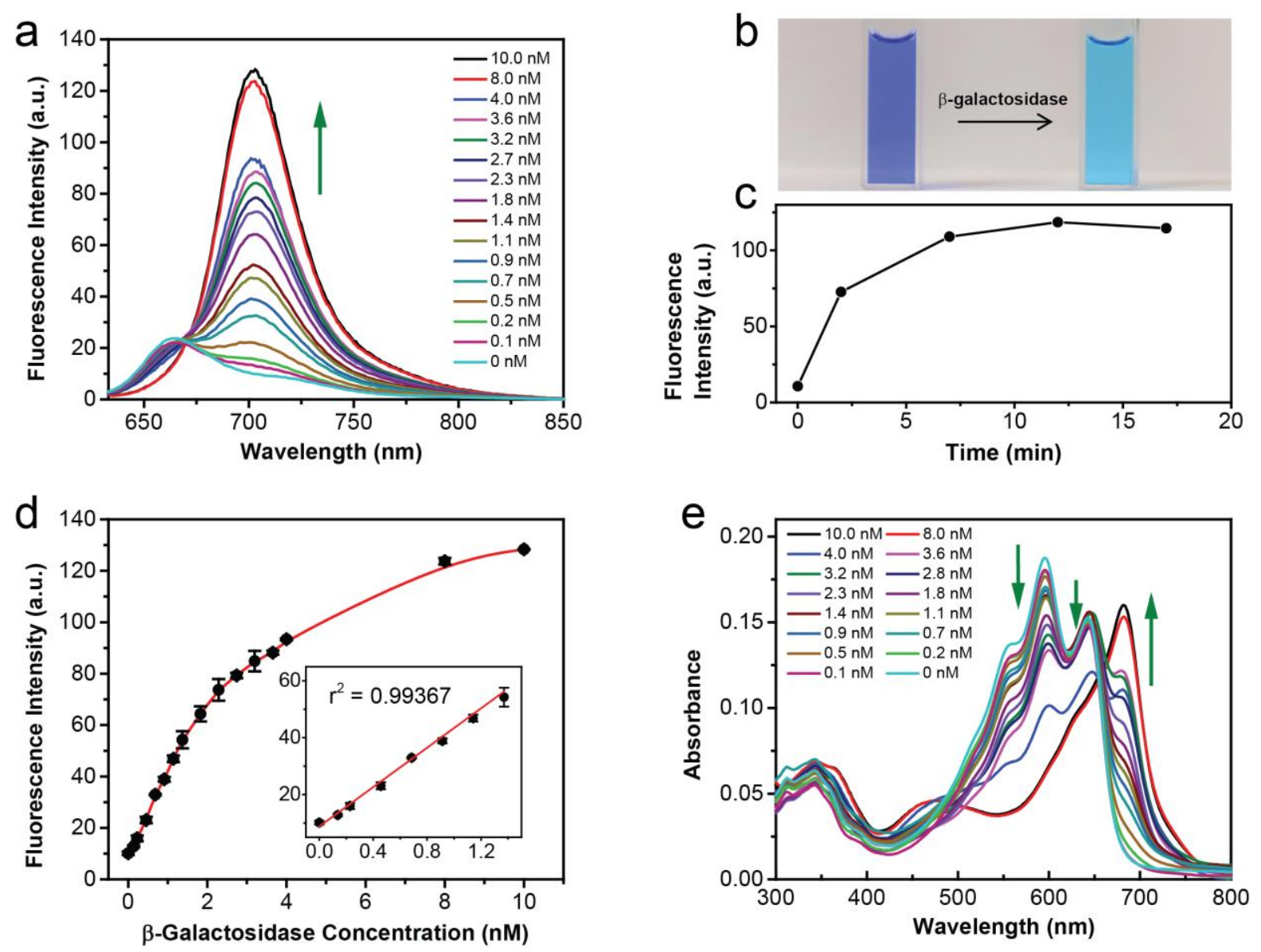

Fig. 2 Absorption and fluorescence responses of Gal-Pro to $\beta$-gal. a: Fluorescence spectra of Gal-Pro after incubating with various concentrations of $\beta$-gal in PBS at $37^{\circ} \mathrm{C}$ for $10 \mathrm{~min}$. b: color changes of Gal-Pro solution in PBS before and after incubating with $20 \mathrm{nM} \beta$-gal in PBS at $37^{\circ} \mathrm{C}$ for $30 \mathrm{~min}$. c: time dependence of Gal-Pro fluorescence intensity $(703 \mathrm{~nm})$ in the presence of $5.6 \mathrm{nM} \beta$-gal in PBS at $37^{\circ} \mathrm{C}$. d: fluorescence intensity of Gal-Pro (at $703 \mathrm{~nm}$ ) changes in response to different concentrations of $\beta$-gal after the incubation in PBS at $37^{\circ} \mathrm{C}$ for $10 \mathrm{~min}$. e: absorption spectra of Gal-Pro $(5 \mu \mathrm{M})$ after incubating with various concentrations of $\beta$-gal in $\mathrm{PBS}$ at $37^{\circ} \mathrm{C}$ for $10 \mathrm{~min}$. 


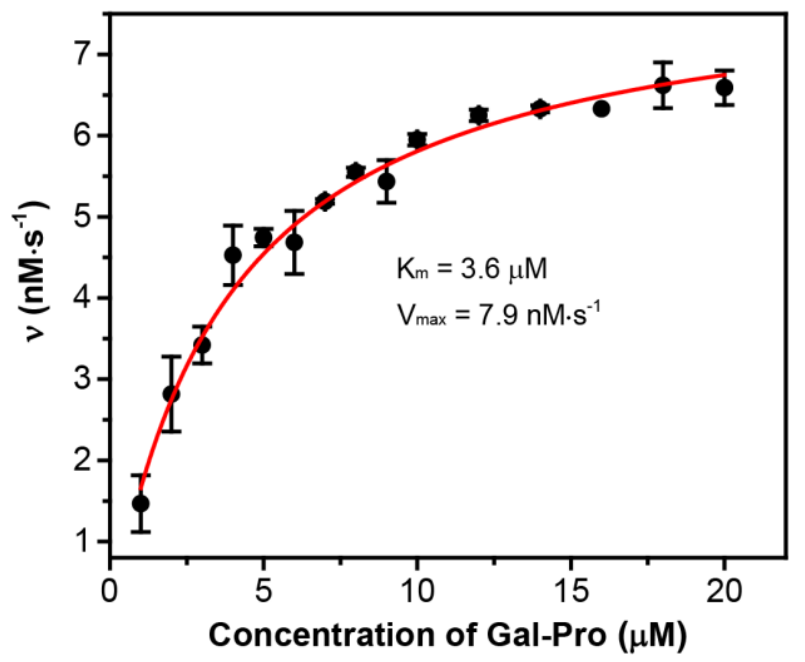

Fig. 3 Steady-state kinetics of enzymatic reaction between the probe and $\beta$-galactosidase. The initial velocity ( $v$ ) was measured using $1 \mathrm{nM} \beta$-gal in PBS ( $\mathrm{pH}$ 7.4) at room temperature and it was plotted against concentration of Gal-Pro. The red curve is the nonlinear fitting using Michaelis-Menten equation, from which the kinetics parameters were obtained. 


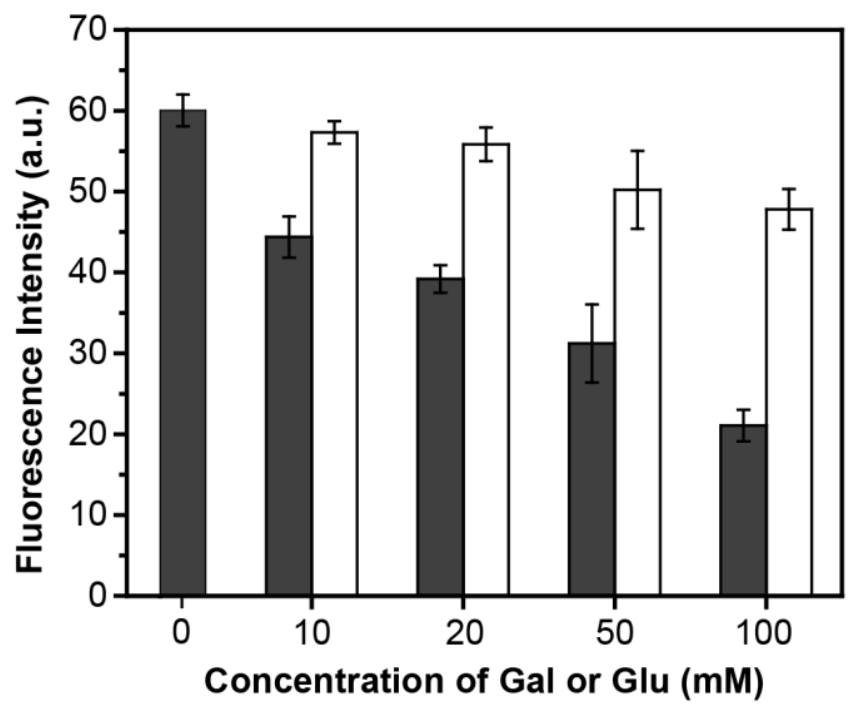

Fig. 4 Fluorescence intensities of $5 \mu \mathrm{M}$ Gal-Pro at 703 $\mathrm{nm}$ upon incubating with $4.6 \mathrm{nM}$ of $\beta$-galactosidase in $1 \mathrm{x}$ PBS (pH 7.4) in the presence of $0,20,50,100 \mathrm{mM}$ of galactose (grey bar) or glucose (white bar). The incubations were conducted at $37^{\circ} \mathrm{C}$ for $10 \mathrm{~min}$. 


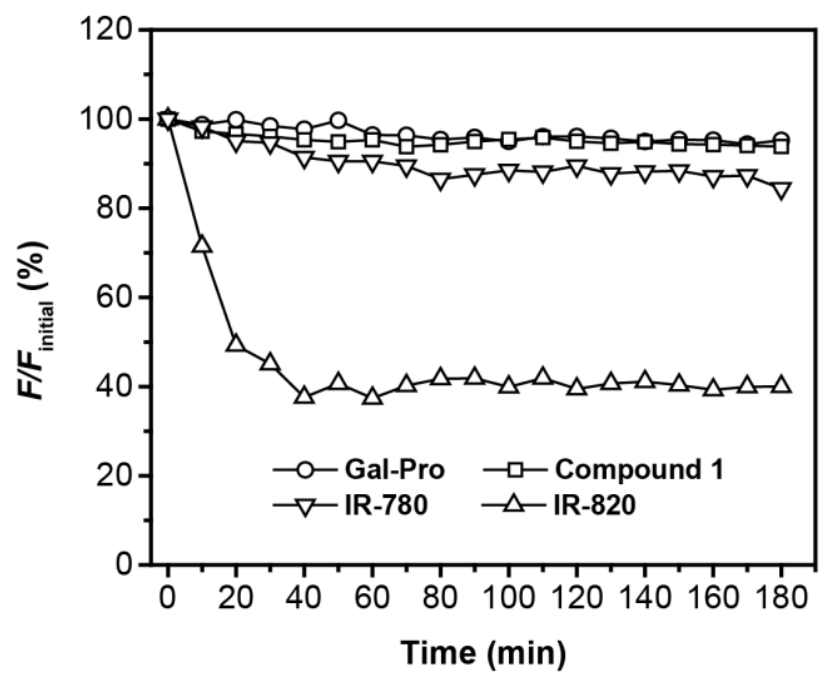

Fig. 5 The photo-stability measurement of Gal-Pro, compound 1, commercial dyes IR-780 and IR-820 in 1x PBS. All sample concentrations were kept as $5 \mu \mathrm{M}$ and sample solutions were measured under sustained excitation at $620 \mathrm{~nm}$ (by a spectrofluorometer) for $3 \mathrm{~h}$ with time interval of $10 \mathrm{~min}$. The ratio of fluorescent intensity $(F)$ to initial fluorescent intensity $\left(F_{\text {initial }}\right.$, time $\approx 0$ ) was collected at $703 \mathrm{~nm}$ for Gal-Pro and Compound 1; $802 \mathrm{~nm}$ for IR-780; $825 \mathrm{~nm}$ for IR 820 . 

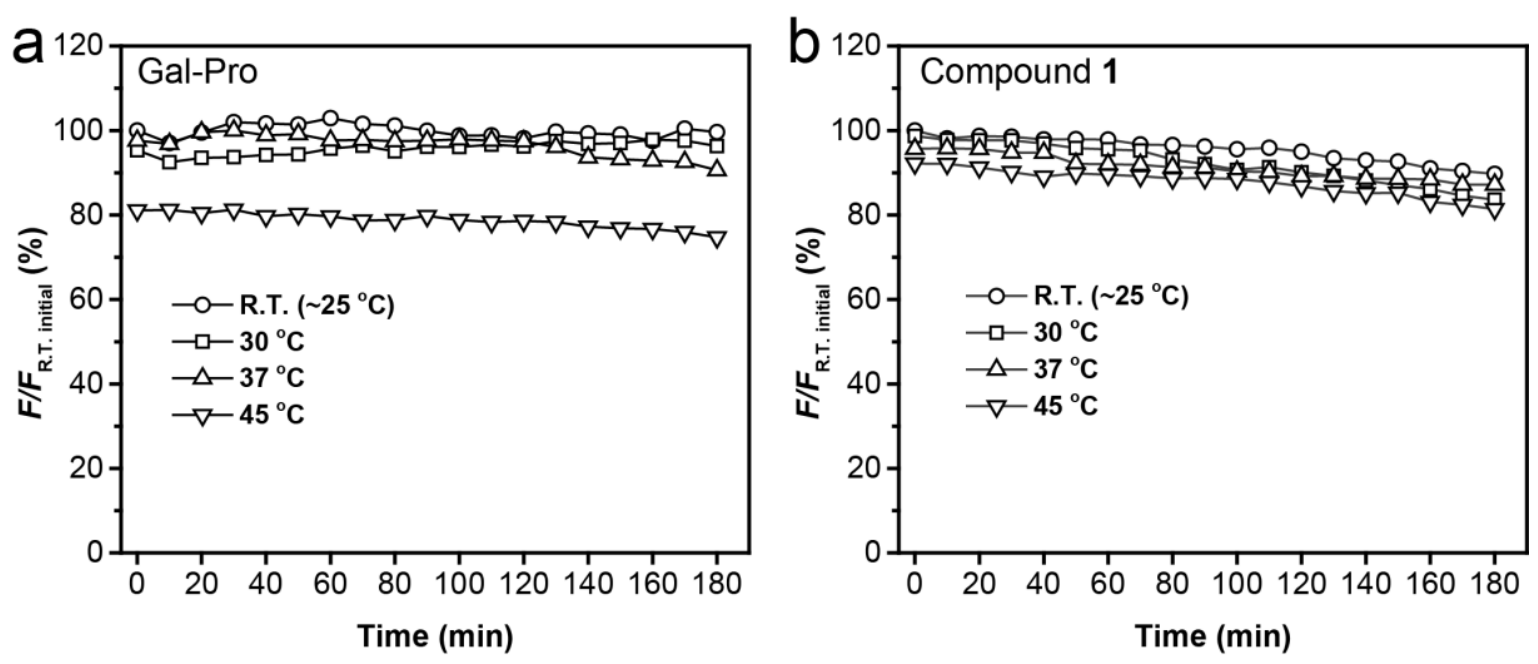

Fig. 6 The thermo-stability measurement of Gal-Pro (a) and its enzyme cleavage product compound 1 (b) in 1x PBS. All sample concentrations were kept as $5 \mu \mathrm{M}$. The ratio percentage of fluorescent intensity $(F)$ to the initial fluorescent intensity at room temperature $\left(F_{\text {R.T. initial }}\right)$ was measured at different temperatures for $3 \mathrm{~h}$ with time interval of $10 \mathrm{~min}$. The fluorescent intensity was collected at $665 \mathrm{~nm}$ and $703 \mathrm{~nm}$ for Gal-Pro and Compound 1, respectively.

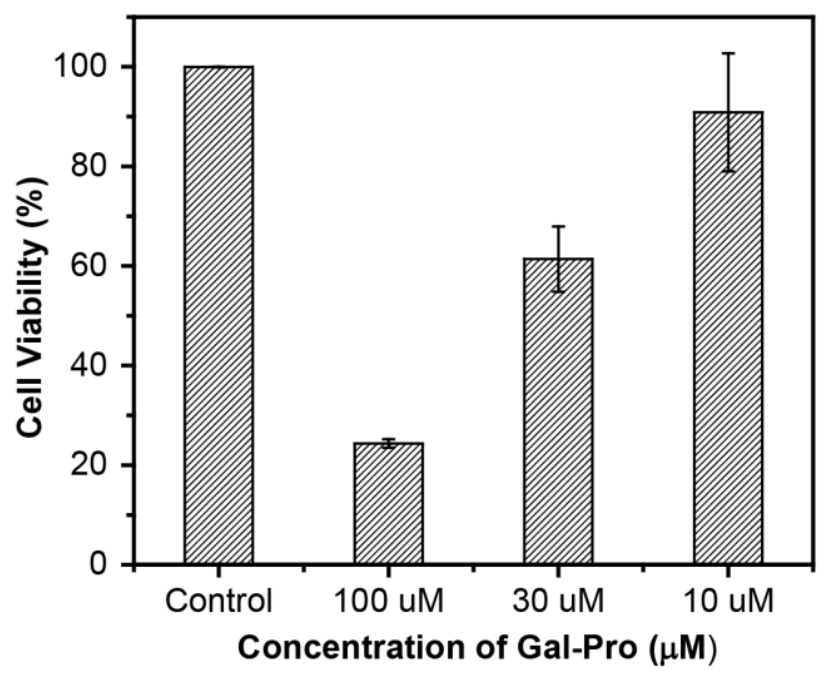

Fig. 7 Concentration effect of the probe on cell proliferation measured by MTS assay. HDF cells were incubated with $10,30,100 \mu \mathrm{M}$ of Gal-Pro for $48 \mathrm{~h}$. To this, $20 \mu \mathrm{L}$ of MTS reagent was added per well, and absorbance at $490 \mathrm{~nm}$ was measured to determine cell viability. Error bars indicate $\pm \mathrm{SD}$ of triplicate measurements. 


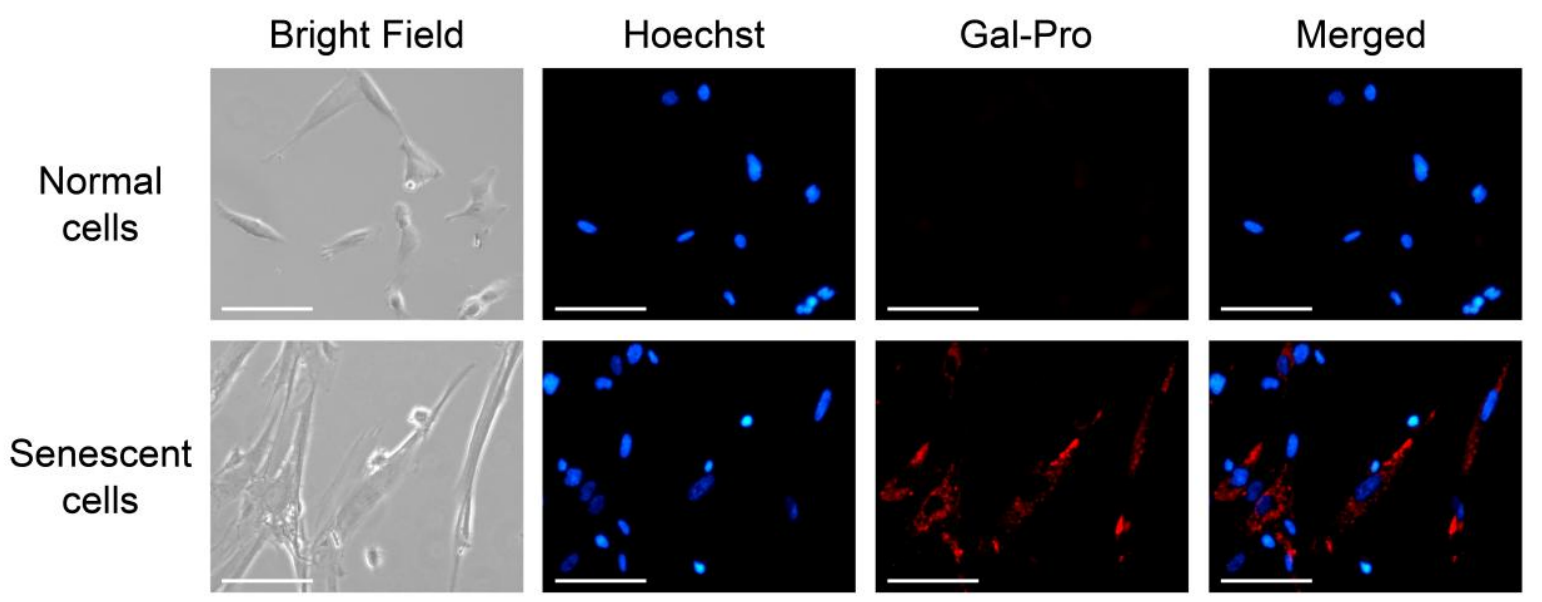

Fig. 8 Fluorescence images of human diploid fibroblast (HDF) cells incubated with $10 \mu \mathrm{M}$ Gal-Pro. HDF cells were incubated with the probe for $2 \mathrm{~h}$ in serum free medium and imaged with $1 \mu \mathrm{g} \cdot \mathrm{mL}^{-1}$ Hoechst 33342 as co-stain. Images were acquired using an inverted fluorescence microscope (AMF4306, $\left.\mathrm{EVOS}_{\mathrm{fl}}, \mathrm{AMG}\right)$ at 20x magnification; scale bars $=100 \mu \mathrm{m}$. 


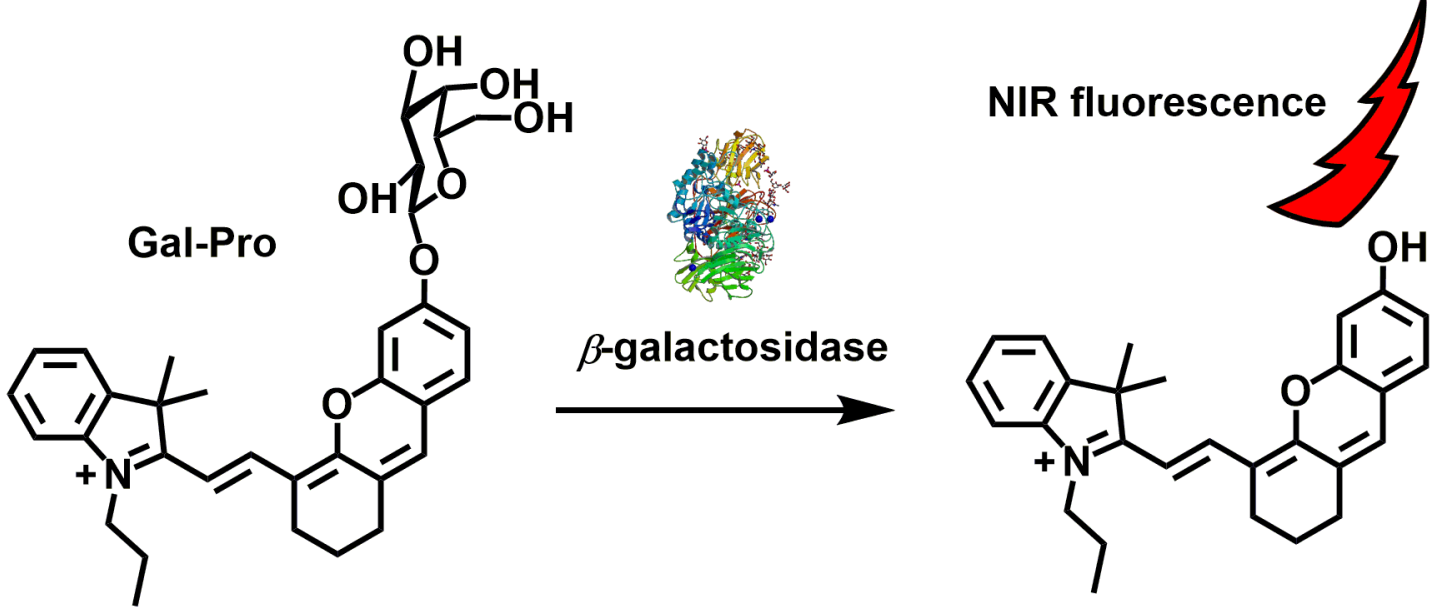

